\title{
MORTON HORWITZ AND HIS CRITICS: A CONFLICT OF NARRATIVES
}

\author{
Robert W. Gordon*
}

This Symposium contemplates a master scholar and his work, but happily not in an obituary way. The scholar is not only very much still with us, but briskly plugging away at his massive Holmes Devise History of the Warren Court, in debonair defiance of the curse of doom that has struck down so many predecessors in their quest to finish Holmes Devise Histories of the Supreme Court. Since this is the kind of occasion that puts one in a reminiscent frame of mind, I want to recall for you the place and time in which I first saw Morton Horwitz, a seminar room at Harvard Law School in the fall of 1969, where he was teaching his first course in American Legal History as a Warren Fellow, and I was a second-year law student. The time was a slumbering winter of American Legal History. A brilliant, but brief Indian summer of the field had ended. Mark DeWolfe Howe had died in 1967. Willard Hurst, who continued to be astonishingly productive for the next twenty years, had already published his best work. ${ }^{1}$ Few could guess at the new growth gestating in the frozen ground-the new legal histories of William Nelson, Harry Scheiber, Lawrence Friedman, Morton Horwitz, and Ted White among others-and the luxuriant spring and summer of the field to come. In Morton Horwitz's classroom, the instructor paced the room like a restless leopard, if one can imagine a chain-smoking leopard. The young Winston Churchill once remarked earnestly to a young woman, "We are all worms. But I do believe that I am a glow-worm." ${ }^{22}$ This is how we felt about the young, febrile, Morty Horwitz. He glowed. He was then assembling the pieces of the story that eventually became The Transformation of American Law, 1780-1860 ("Transformation $I$ "). ${ }^{3}$ Some of us in that class had already read through what was then the slender bibliography-not more than twenty or thirty books and articles in all-of works worth reading in American Legal History; and had an inkling of

* Johnston Professor of Law and History, Yale Law School.

1. James Willard Hurst, The Growth of American Law: The Law Makers (Little, Brown \& Co. 1950); James Willard Hurst, Law and the Conditions of Freedom in the Nineteenth Century United States (U. Wisc. Press 1967); James Willard Hurst, Law and Economic Growth: the Legal History of the Lumber Industry in Wisconsin, 1836-1915 (Belknap Press of Harv. U. Press 1964) [hereinafter Law and Economic Growth].

2. Roy Jenkins, Churchill: a Biography 137 (Farrar, Straus, and Giroux 2001) (quoting Violet Bonham Carter).

3. Morton J. Horwitz, The Transformation of American Law, 1780-1860 (Harv. U. Press 1977). 
the originality and daring of the argument Horwitz was developing before us. Stanley Katz was in the class that fall (already an established historian, he was spending the year at Harvard as a liberal arts fellow). One day we walked out of the class together-it was the class in which Horwitz explained how negligence had evolved out of neglect of quasi-contractual duty and been transmuted to mean actions in excess of statutory jurisdiction and thence to something like "fault"and looked at each other; and Stan said what was on both our minds: "something extraordinary happened in that class today."

When Transformation I appeared in 1977, it made a big splash-perhaps not quite as big as Charles Beard's Economic Interpretation of the Constitution (1913) - but certainly big for a book about legal history, and a pretty complicated and densely written book at that. Historians loved it and gave it the Bancroft Prize in 1978. Some legal historians liked it too-Willard Hurst and (at least initially) Harry Scheiber gave it favorable though cautiously qualified reviews. ${ }^{4}$ But many of the reviews from lawyers were negative. There were criticisms both of the broad substantive arguments and of various matters of detail. Some of these were well taken, others less so. I will not undertake in this short essay a comprehensive survey of the reviews. That task has already been admirably performed, first by Wythe Holt twenty years ago, and with wit, spirit and fresh insight by Laura Kalman in this Symposium. ${ }^{5}$ But I would like to try to identify and comment on some general themes of the critiques.

In my view the most justified of the general critiques was that Horwitz had written an intellectual history of legal ideas and doctrines, and then had extrapolated from that history conclusions about social effects. The thesis was, of course that judges of the early republic, working in concert with commercial interests, had worked a revolution in property, tort, and commercial law, which had redistributed wealth away from groups identified as "farmers, workers and consumers" and into the hands of "entrepreneurs." Once this was accomplished, the judges had hardened the new legal status quo into one of absolute rights, in order to protect the property thus expropriated and transferred against further populist redistribution. The most justified critique, I think, was the simple one that Horwitz's evidence, being all of change internal to the legal system and drawn exclusively from appellate cases and treatises, could not support strong conclusions about social alliances and social effects. The law on the books is not the law in action. If he had looked for such evidence, I believe, it would have confirmed his argument about alliances and effects in some respects, and made it problematic in others.

The thesis about alliances would surely not be hard to support. Proving that the top bracket of American lawyers from 1800 onward-the lawyers who tended to become judges-were allied with, or at least held views in common with,

4. Willard Hurst, Book Review, 21 Am. J. Leg. History 175 (1977); Harry N. Scheiber, Back to "the Legal Mind"? Doctrinal Analysis and the History of Law, 5 Rev. in Am. History 458 (1977).

5. Wythe Holt, Morton Horwitz and the Transformation of American Legal History, 23 Wm. \& Mary L. Rev. 663 (1982); Laura Kalman, Transformations, 37 Tulsa L. Rev. 849 (2002). 
"commercial interests," would be like trying to prove the proposition that "bankers were strongly allied with depositors." The bar elite in the nineteenth century was in part defined, as it is today, by the wealth, social standing, and economic importance of its principal clients. Lawyers invested in their clients' business ventures, drew on them to finance their political campaigns, and intermarried with their families. ${ }^{6}$ Such connections do not, of course, mean that lawyers who became judges were nothing more than mouthpieces and deputies of their former clients, or that in their roles as interpreters of statutes and developers of common and constitutional law they were incapable of taking a somewhat independent line on what the law required. But they were usually drawn from the same strata of society and shared the same general ways of thinking about what the public interest required.

In their ways of thinking, however, the "commercial interests" themselves were more divided than Horwitz's treatment allows, and divided especially by views on the proper role law should play in economic development and the primacy of economic growth over competing values. In one of the most valuable, though unaccountably and undeservedly neglected, of the many works inspired by the Horwitz thesis, a pioneering study by Tony Freyer of antebellum law and lawyers in New Jersey, Maryland, Delaware, and Pennsylvania discovered sharp conflicts between corporate "capitalists" and local "producers" over how economic development should proceed and who should bear its costs. The "producers" and their lawyers continued to maintain and defend interests in equitable distribution of the proceeds of economic growth and a moralized view of political economy as an instrument of values such as republican citizenship and community cohesion. In legal contests, because of their commonality of interest with local juries, the producers were often able to triumph over the capitalists.

The thesis about the social effects of changes in legal rules is obviously a lot more complicated. For example, Horwitz argued that tort law in this period shifted from a strict liability (or presumption of compensation for harm) to a negligence standard, with the result that industrial defendants were effectively immunized from liability. ${ }^{8}$ In one of the extensive empirical critiques, Gary Schwartz challenged this conclusion, maintaining that fault liability had always been the norm and pointing out that plaintiffs won many of the tort cases, though he conceded that workers generally lost. ${ }^{9}$ Subsequent work, not available to Horwitz or his critics in the 1970s, has clarified that both these positions are pretty much beside the point, because the effective prevailing standard in tort-

6. For illustrative studies, see e.g. Maurice Baxter, One and Inseparable: Daniel Webster and the Union (Belknap Press of Harv. U. Press 1984); Alfred S. Konefsky, Law and Culture in Antebellum Boston, 40 Stan. L. Rev, 1119 (1988); R. Kent Newmyer, Supreme Court Justice Joseph Story: Statesman of the Old Republic (U. N.C. Press 1985).

7. See generally Tony A. Freyer, Producers versus Capitalists: Constitutional Conflict in Antebellum America (U. Press Va. 1994).

8. Horwitz, supra n. 3, at 97-108.

9. See Gary Schwartz, Tort Law and the Economy in Nineteenth Century America: $A$ Reinterpretation, 90 Yale L.J. 1717 (1981). 
especially personal injury-cases until late in the nineteenth century was neither strict liability nor negligence, but effectively no liability. For a variety of reasons (employer paternalism, strong disincentives to sue employers, low levels of rightsconsciousness, conservative judges, lawyers' fees, witness disqualification rules, etc.) almost nobody ever sued. ${ }^{10}$ When the injured eventually did begin to litigate, it turns out, the damages and settlements they recovered were so low as to be almost derisory. ${ }^{11}$

Other work has further complicated Horwitz's thesis of a "subsidy" to capitalists affected by immunity or low damage awards for nuisances and takings by eminent domain. Nuisance doctrine remained schizophrenic throughout the nineteenth century, sometimes awarding compensation or injunctions to neighboring landowners for damage from nearby mining and manufacturing operations and sometimes denying them. ${ }^{12}$ Freyer found that local landowners who invoked statutory proceedings for assessing compensation for takings by corporate enterprises were often able to recover more than market value because of the sympathy of the local assessors. ${ }^{13}$ Appeals to the courts (some of whose judges were indeed investors in developers' ventures, but who were politically connected to local "producer" as well as "capitalist" interests) sometimes lowered such assessments, but usually upheld them. ${ }^{14}$

Some reviews challenged Horwitz's doctrinal rather than his (implicit) social history. The most prominent of these was Brian Simpson's critique of Horwitz's thesis on the transformation of contract law. ${ }^{15}$ Horwitz-I am simplifying an intricate technical quarrel-argued that contract law shifted from an eighteenthcentury pattern in which juries enforced contracts according to community-based moral expectations of fair and equitable exchange, to a mid-nineteenth century pattern of awarding expectation damages for breach of the strict terms of express executory promises. He described in short a shift from enforcement of bargains on fair terms to enforcement of the "will of the parties" as expressed in the formal terms of their agreements. Simpson said that Horwitz was wrong to see the will or

10. See generally Robert B. Rabin, The Historical Development of the Fault Principle: $A$ Reinterpretation, 15 Ga. L. Rev. 925 (1981); Lawrence M. Friedman, Civil Wrongs: Personal Injury Law in the Late 19th Century, 1987 Am. Bar Found. Res. J. 351 (1987); John Fabian Witt, Toward a New History of American Accident Law: Classical Tort Law and the Cooperative First-party Insurance Movement, 114 Harv. L. Rev. 690 (2001).

11. Friedman, supra n. 10, at 365-67.

12. See e.g. Robert Bone, Normative Theory and Legal Doctrine in American Nuisance Law: 1850 to 1920, 59 S. Cal. L. Rev. 1101 (1986). Bone discusses a classic set of cases that deal with the protracted litigation between Sanderson, a landowner, and the Pennsylvania Coal Co. In the first case the Pennsylvania Supreme Court allowed the landowner to enjoin a coal company from emitting coal dust that polluted the plaintiff's stream, on the ground that the plaintiff had an absolute right to undisturbed enjoyment of his property. Pa. Coal Co. v. Sanderson, $86 \mathrm{~Pa} .401$ (1878). Eight years later, the same court, in a fourth decision with the same parties before it on the same facts, refused to give any remedy on the ground that the coal company had an absolute right to make "natural" use of its property, which in its case was mining coal, notwithstanding any "incidental" damage to its neighbors. Sanderson v. Pa. Coal Co., 113 Pa. 126, 6 A. 453 (1886).

13. Freyer, supra n. 7 , at 152 .

14. Id. at $160-65$.

15. A.W.B. Simpson, The Horwitz Thesis and the History of Contracts, 46 U. Chi. L. Rev. 533 (1979). 
consent theory as a nineteenth century innovation; it was already embedded in common law contract doctrine by the mid-eighteenth century. What Horwitz was seeing, Simpson suggested, was something quite different, not a change in the law, but the "progressive dethronement of the jury," "accompanied by the generation or reception of law in order not so much to replace or transform older doctrine as to provide law where before there was little or none."16

In the same year as Simpson's article, however, the Horwitz thesis received a significant hormone boost from Patrick Atiyah's massive Rise and Fall of Freedom of Contract (1979), which told a story similar to Horwitz's about the evolution of modern English contract law. Through the eighteenth and early nineteenth centuries, Atiyah said, the law of contractual obligations was largely a law enforcing equitable returns (what we would now call reliance or restitution interests) for already executed contract performances. Only in the nineteenth century did the executory contract, and legal enforcement of parties' mutually agreed-upon promises, become the "paradigm of contract theory."17 In 1992, James Oldham judiciously reviewed the entire controversy in his edition of the manuscripts of Lord Mansfield, the great eighteenth-century English commercial law judge. Oldham granted to Simpson and his allies their point about contract doctrine: the consent theory and the action on the executory promise had certainly been recognized in legal doctrine by Mansfield's time. But, Oldham said, the "great majority" of the decided cases of the time largely support the HorwitzAtiyah story, since the contracts actually sued on were mostly executed contracts and "contract and quasi-contract were congenial parts of an overall philosophy of moral transactional behavior that required the honoring of legitimately created expectations and the return of benefits unjustly acquired."18

More interesting, however, were the reviews that did not just criticize the book, or try to pick apart its arguments and evidence, but that obviously hated it. The book genuinely affronted them-much as readers had been by Beard's had affronted his readers - and for similar reasons. Horwitz had committed a sort of sacrilege. As John Reid put it, speaking of Horwitz as one of a new clan of leftwing historians, "The iconoclasts have invaded the temple of legal history. They have smashed the fetishes, blotted out the frescoes, and desecrated the tombs. If we do not force them to the evidence, they will even desacralize Clio."19 This was not quite as good as one of the headlines greeting Charles Beard's book, "SCAVENGERS, HYENA-LIKE, DESECRATE THE DEAD PATRIOTS WE REVERE," 20 but it was in the same spirit. As Beard had pulled down the Founders from their lofty perch of disinterested farsighted statesmen, and recast

\footnotetext{
16. Id. at 600 .

17. P.S. Atiyah, The Rise and Fall of Freedom of Contract 419 (Clarendon Press of Oxford U. Press 1979).

18. James Oldham, The Mansfield Manuscripts and the Growth of the Law in the Eighteenth Century vol. 1, 228, 231 (U. N.C. Press 1992).

19. John Reid, A Plot Too Doctrinaire, 55 Tex. L. Rev. 1307, 1321 (1977).

20. Peter Novick, That Noble Dream: The "Objectivity Question" and the American Historical Profession 96 (Cambridge U. Press 1988) (quoting a Headline in the Marion, Ohio Star).
} 
them as men with property in speculation to gain or lose in the new political arrangements of the republic, so too had Horwitz charged that judges of the early republic, the "Golden Age" or "Formative Period of American Law" with participation in a grubby conspiracy to line, if not their own pockets, those of commercial or entrepreneurial elites. Horwitz's narrative, in short, ran sharply and rudely into some of the dominant narratives, and the collision hurt.

What were the prevailing narratives? Horwitz in an earlier iconoclastic essay $^{21}$ had identified some of them as the "conservative tradition" in American legal historiography: a practice of extolling the great judges of the past as guardians of the common law tradition-a "taught tradition," as Roscoe Pound had called it, celebrated as autonomous from political pressures and economic forces, a tradition of purely legal reasoning about purely legal principles, and yet despite (or rather because of) that the great source of limits on popular impulses to level and redistribute property. John Reid's review spoke for that tradition in its suggestion (which Reid however oddly attributed to Willard Hurst) that nineteenth century courts, so far from conspiring with any set of economic interests, "acted as neutral referees, intervening only when one party appealed a question from the marketplace, otherwise permitting contending groups to fight for economic survival without close supervision as long as they did so by certain, general rules."22 Strangely enough, though, it was not until many years later that the authentic ghost of Roscoe Pound materialized in Peter Karsten's Heart versus Head (1997) to reproach Horwitz for having failed to understand that judges decide out of doctrinally stable principle, not ideology or material interest or even just the desire to pursue specific policies such as economic growth. ${ }^{23}$ The main burden of the most severe critiques, including Reid's, was not so much that the judges had been instrumental, but that their work's aims and results were to "subsidize" entrepreneurs and "redistribute" in favor of the rich.

Indeed, had the rest of Transformation I's story remained in the key of Horwitz's opening chapter, I suspect the storm would have been avoided. The book begins with the story of how American judges shift from a view of law as found to law as made, law as a self-conscious engine of social policy. The next chapters identify the main policy as economic development. Judges posed as defenders of vested property rights, when in fact they were Schumpeterian entrepreneurs, destroyers of established property rights, and agents of their

21. Morton J. Horwitz, The Conservative Tradition in the Writing of American Legal History, 17 Am. J. Leg. History 275 (1973).

22. Reid, supra n. 19, at 1321. In a similar spirit, see Randall Bridwell, Theme v. Reality in American legal History: a Comment on Horwitz, The Transformation of American Law, 1780-1860, and the Common Law in America, 53 Ind. L. Rev. 449, 496 (1978) (the common law is a "largely self-ordering system supportive of autonomous individual behavior and experiment, adjusting itself with the aid of limited judicial intervention that does not effectively elevate the narrow interests of 'caste or class"').

23. Peter Karsten, Heart versus Head: Judge-Made Law in Nineteenth Century America (U. N.C. Press 1997). Karsten did not, however, argue that common law judges functioned in a wholly autonomous and socially insulated legal sphere. Occasionally they were motivated to soften the cold reason of the law by considerations of fairness and equity (the "Heart" of his title) grounded in Christian morality. But they never seem to have been motivated by political views or allegiances. 
reassignment to dynamic developers. Horwitz's story breaks here with the older "conservative traditions"- that judges are guided by principle and that they side with established property. But it is perfectly continuous and consistent with the "commonwealth histories" of Oscar and Mary Handlin, Carter Goodrich, Louis Hartz, and the social-legal histories of Willard Hurst and Harry Scheiber, ${ }^{24}$ uncovering a long history of government and legal system promotion of economic development in the early republic and pointing out that it favored dynamic property, not vested property, entrepreneurial rather than rentier interests. Horwitz's Transformation I fit nicely into this line of work by documenting more thoroughly the contribution of the courts, and legal doctrines in decisions and treatises, to this promotional enterprise.

The difference between Horwitz's narrative and theirs was in part that he was much darker and depressive about the outcomes, because he took a fundamentally dimmer view of capitalist development. ${ }^{25}$ (Beard's crime, similarly, was not that he had suggested that the Founders sought to protect property rights against the mob, but that he suggested there was something wrong with that.) These were the vibes the most hostile reviewers picked up and reacted against. I have often heard critics call Horwitz's work "Marxist," though I have never been able to see much of anything Marxist about it, no suggestion whatsoever for example that "in the last instance" struggles between classes produced by dominant relations of production determine social relations or ideological superstructures such as legal doctrines. It seems a more idealist than Marxist story: the lawyers and judges had a choice to make, and they chose to ally themselves with business interests rather than the republican ideals of the Revolution.

Horwitz is drawing on different background narratives of the history of industrial capitalism. One, pretty clearly, is E.P. Thompson's narrative of how the working-class world of English craft artisans was crushed; and how "the moral economy of the English crowd," a communitarian ideology of fair prices and wages and equitable distribution of scarce basic commodities in times of dearth, enforced by the legal system through local magistrates, was displaced by a heartless laissez-faire regime of market prices and wages. ${ }^{26}$ Another is Karl

24. Oscar Handlin \& Mary Flug Handlin, Commonwealth; A Study of the Role of Government in the American Economy: Massachusetts, 1774-1861 (rev. ed., Belknap Press of Harv. U. Press 1969); Carter Goodrich, Government Promotion of American Canals and Railroads, 1800-1890 (Greenwood Publg. Group 1960); Louis Hartz, Economic Policy and Democratic Thought: Pennsylvania 1776-1860 (Chi. Quadrangle 1948); Hurst's works, supra n. 1; Harry N. Scheiber, Ohio Canal Era: A Case Study of Government and the Economy, 1820-1861 (Ohio U. Press 1987).

25. Not, by the way, that his predecessors were wholly complacent. Hartz had described with biting clarity how mid-century corporations had appropriated the Jacksonians' originally anti-corporate individualist ideology and turned it in their favor against state regulation. Hartz, supra n. 24, at 113-22. Hurst, a Progressive New Dealer-far from calling nineteenth century law either efficient or just-said it exuded a "bastard pragmatism" focused on short-term gain and oblivious to larger social ends. Hurst, Law and Economic Growth, supra n. 1, at 34-37 and passim. Scheiber described how courts had aided the expropriation of property on behalf of transport companies. Harry N. Scheiber, Property Law, Expropriation, and Resource Allocation by Government: The United States, 1789-1910, 33 J. Econ. History 232 (1973).

26. E. P. Thompson, The Moral Economy of the English Crowd in the Eighteenth Century, in E. P. 
Polanyi's brilliant and terrifying narrative of industrial capitalism in The Great Transformation (1944), as a total pulverizing of traditional social ties and social life and the conversion of all social relations into relations of calculated exchange of commodities in impersonal markets. The spirits of Thompson and Polanyi loom most visibly over Horwitz's chapter on contract law, with its story of communal conceptions of fair exchange being supplanted by the "will theory" and the legal enforcement of contracts on whatever terms one party could demand or compel from another. ${ }^{27}$ But they are present throughout the entire book. When Hurst wrote of law's displacing "vested rights," he was thinking of rentier landlords and fox-hunting squires. Horwitz implicitly presents a more Thompsonian story, of customary expectations of fair prices, and of traditional collective use-rights; of juries settling disputes among neighbors according to communal norms, rather than remote judges enforcing rules favoring commercial strangers and outsiders and unconcerned with equity and morality. And surely, in Horwitz's identification of the winners and losers from capitalist development, there is more than a hint of Charles Beard's economic populism. Horwitz was reaching back into the histories of the Progressive period and the 1930s, and the new left-wing social histories of the 1960 s, for narratives to fuel his rebellion against the scholarship of the 1950s, the pages of yesteryear when consensus-minded Cold Warriors kept law and order on the fields of historical scholarship.

Still other background presences to his book are cheering his rebellion from 1950s legal scholarship: the Legal Realists of the 1920s and 30s and contemporary work of the Critical Legal Studies movement, of which he was one of the founders and most eminent members. The signs of these influences are in his distrustindeed disgust-with legal formalism, meaning here, the pose of judges and treatise-writers that they are speaking for a general, apolitical, neutral body of legal principles. Such principles always conceal, for Horwitz, a right-wing political agenda and ideological bias. He was even led to a severe criticism of the admired E.P. Thompson. In the concluding chapter of Whigs and Hunters (1975)-a generally Beardian book about how the English upper-class had twisted and manipulated the law to divest traditional rights to take deer, graze cattle, and glean corn from harvests, to protect the landowner's absolute and enclosed property, and to punish customs as crimes-Thompson ended with an unexpected paean of praise for the "rule of law" as an "unqualified human good"-for all its abuses, a great western institution that limits the rulers as well as the ruled. ${ }^{28}$ The formalist view of the rule of law, Horwitz chided, always conceals inequalities of wealth and power under a facade of formal equality, and delegitimates attempts to remedy such inequalities. ${ }^{29}$

For their part, some of Horwitz's critics were speaking out of competing

\footnotetext{
Thompson, Customs in Common 185 (New Press 1993).

27. Horwitz, supra n. 3, at 160-88.

28. E. P. Thompson, Whigs and Hunters: The Origin of the Black Act 258-69 (Pantheon Books 1975).

29. Morton Horwitz, The Rule of Law: An Unqualified Human Good?, 86 Yale LJ. 561, 566 (1977).
} 
narratives of their own, some old, some new. Reid very straightforwardly adopted the traditional narrative of American legal-economic development as progress away from feudalism and mercantilism and toward economic liberalism. For Reid, the law's shift from enforcing just prices to express promises was a lifting of restraints on commerce and freedom. Similarly Chief Justice Shaw's decision in Farwell, ${ }^{30}$ immunizing employers from vicarious liability for harms caused by fellow-servants, on the ground that workers had impliedly contracted to assume the risk-which Horwitz had called a redistributive rule-change subsidizing railroads at the expenses of workers-was, for Reid, simply the fulfillment of the Revolution's principle of freedom of contract: "the individual, free to enter or reject a perilous employment, was made responsible for his own decisions." "31

Another of Horwitz's hostile critics, Stephen Williams, then a professor at Colorado law school, now a distinguished federal judge, attacked him from the perspective of Chicago law-and-economics, in a review called Doubtful Economics Makes Doubtful History. Williams made some valuable points: he was really puzzled about why Horwitz would want to privilege stable property rights in first occupiers, such as riparian users or farmers, against later-competing users. I agree that this preference, in a man generally speaking of the left, for absolute property rights (and pre-commercial societies) is a little hard to understand: it makes sense, I think, only in a Polanyi/Thomson narrative in which such stable use rights are aspects of stable communities. It also makes sense to an ironic narrative-one in which judges and lawyers totally committed to preserving absolute property rights end up totally subverting them. Williams also asked some good analytic questions: when can a set of legal rule changes with distributional impacts be labeled "subsidies?" What's the baseline? And he also filled a gap Horwitz had left by summarizing some data from economic history about changes in income and wealth distribution in the antebellum United States, though the data was too aggregate to either confirm or refute Horwitz's basic thesis, and of course shed no light either way on how, if at all, legal rule-changes affected basic distributive shares. ${ }^{32}$ But Williams's more basic point was to express doubt that law had

30. Farwell v. Boston \& Worcester R.R., 45 Mass. 49 (1842) (opinion of Shaw, C.J.).

31. Reid, supra n. 19, at 1317. Reid reasonably asks the historian to interpret the fellow-servant rule in the light of contemporary, rather than modern, views of freedom of contract. Even doing that, however, it is difficult to reconcile the fellow-servant cases with doctrines being developed at the same time to deal with contracts between railroads and shippers and passengers, which explicitly refuse to allow the railroads to contract out of liability even expressly, on the grounds that the other parties have no real opportunity to withhold consent from such contracts. Even in mid-nineteenth century America, the problems of the one-sided contract of adhesion were perceptible, if only selectively so, to the legal system.

32. Stephen Williams, Transforming American Law: Doubtful Economics Makes Doubtful History, 25 UCLA I. Rev. 1187, 1210-11 (1978). Williams reported the evidence from economic history as showing no significant changes in wealth distribution in the antebellum United States. A more recent review of the data indicates however that "[a]ll the fragments of unsatisfactory evidence taken together may justify a conclusion that wealth inequality increased somewhat during the nineteenth century, at least in the antebellum period." Clayne Pope, Inequality in the Nineteenth Century, in The Cambridge Economic History of the United States vol. 2, 109, 135 (Stanley L. Engerman \& Robert E. Gallman eds., Cambridge U. Press 2000); Jenny Wahl, Twice-told Tales: An Economist's Re-telling of The Transformation of American Law, 1780-1860, 37 Tulsa L. Rev. 881 (2002). 
become more instrumental (or "utilitarian") in the early nineteenth century. He drew on a competing narrative, this one of Chicago law-and-economics (which was I believe itself a completely unconsciously repeating of a nineteenth century narrative of the progressive evolution of the common law) to the effect that the "common law" was generally both utilitarian and efficient, indeed had been efficient for many centuries, as in its long struggle against restraints on alienation. $^{33}$ This argument surely proved a bit too much. For if the law is efficient when it loosens feudal restraints, how can it be efficient when it creates them? And if the law is efficient when it does away with just-price doctrines and enforces contracts according to their strict terms, what was it before it thus reformed itself? If the Mill Acts are efficient because, by converting property to liability rules, they prevent holdout landowners from thwarting progress by injunction, why did the rule have to change?

In hindsight perhaps the most surprising fact about the reviews of Transformation $I$ is that Horwitz's severest critics came mostly from the right, not the left. The book appeared after all in 1977, in the full flowering of post-1960s social history "from the bottom up." One would have expected some critics to fault Horwitz's book for focusing on the quarrels of white men who could afford to fight cases to appeal, and leaving out all the law of social relations of novel concern-the law of slavery, indentured servants, the employment relation and labor organizing, the law of sex roles, marriage and the family, the criminal law as an agent of social repression and discipline. The closest to such a critique was Wythe Holt's, but in the course of an exceptionally warm and generous overall review. ${ }^{34}$ The answer must be that in the 1970 s and 80 s the space for any kind of legal left was very small, Horwitz was one of its few occupants, and for once leftwing scholars passed up the usually irresistible opportunity to savage one of their own.

The reception accorded to Horwitz's second volume, The Transformation of American Law 1870-1960: The Crisis of Legal Orthodoxy ("Transformation IT"), was altogether different in kind. I found only one really hostile review, by the conservative lawyer Bruce Fein in The Washington Times, which dismissed Horwitz's intellectual history as a story of scholastic disputes, and provided a delicious illustration of the continuing power of "classical" ideology by dismissing all Progressive statutory innovations on the common law-such as minimum wage laws-as rent seeking by special interests trying to get themselves a better deal than they could get through the market. ${ }^{36}$ Most of the major reviews, ${ }^{37}$ while

33. Williams, supra n. 32, at 1200-05.

34. Holt, supra n. 5, at 719-22.

35. Morton J. Horwitz, The Transformation of American Law 1870-1960: The Crisis of Legal Orthodoxy (Oxford U. Press 1992).

36. Bruce Fein, Straining to Bring Forth a Legal Gnat, Wash. Times G3 (Aug. 13, 1992).

37. See e.g. Daniel R. Ernst, The Critical Tradition in the Writing of American Legal History, 102 Yale L.J. 1019 (1993); Robert W. Gordon, The Elusive Transformation, 6 Yale J.L. \& Humanities 137 (1994); James Kloppenberg, The Theory and Practice of American Legal History, 106 Harv. L. Rev. 1332 (1993); John Henry Schlegel, A Tasty Tidbit, 41 Buffalo L. Rev. 1047 (1993); G. Edward White, Transforming History in the Postmodern Era, 91 Mich. L. Rev. 1315 (1993). 
politely challenging, were exceedingly respectful, as if trying to temper the howling winds that had surrounded Transformation $I$. Their emphasis was also different. The reviews of Transformation I centered, I have argued, on a conflict of narratives. Those of Transformation $I I$ were much more about methodology, and especially the vexed connections, on which Horwitz now had a very different take, between intellectual and social history.

Transformation $I$ was mostly about doctrine, and argued that doctrine caused social change. Transformation II was mostly about the more abstract legal "thought" of treatises and articles, and argued a more complex view of its relation to social change. In Transformation II legal thought sometimes rationalized and legitimated social changes that had already taken place. But sometimes it influenced future social change by operating as an ideological filter of reality as its categories and assumptions shaped the ideological lens through which lawyers looked, one that conditioned their views of what was possible and desirable, public and private, coercive pressure and free contract, faulty or innocent conduct, cause and accident.

Like Transformation I, Transformation II drew upon background narratives. One remained the standard Progressive story of how Progressive (including Legalrealist) jurists had challenged the socially conservative formalism of "Classical Legal Thought" (though Horwitz complicated the picture by showing that classical-individualism had actually been hostile to corporate concentration). Another narrative, worked out with his colleague Duncan Kennedy ${ }^{38}$ explained the main contribution of Realism as the smashing of the public-private distinction in classical law, the insight most shrewdly developed by Robert Hale that no legal regime is neutral, and no market is "free," that all legal regimes including "laissezfaire," enable some interests to command and coerce and injure others by means of state power. ${ }^{39}$

But there were two meta-narratives as well, which shaped Horwitz's project much as he argued legal thought had shaped twentieth century legal doctrines and policies. One was borrowed from Thomas Kuhn's Structure of Scientific Revolutions (1962), and its theory of paradigm shifts generated by the accumulating strain of disconfirming and anomalous events: at some point, the strain is too much, the old theories lose their plausibility and fall apart, and new ones that appear to promise a more powerful and coherent account of perceived realities supplant them. The other came from Peter Novick's remarkable history of American history-writing in the twentieth century, That Noble Dream (1988), in which, one might say, Novick brought the methods of legal-realism to bear on the historical profession's claims to objectivity in historical scholarship. Between them, Kuhn and Novick helped supply Horwitz with both a story-line for his new

38. Kennedy's path-breaking and widely influential thesis of his legal history course materials is briefly summarized in Duncan Kennedy, Toward a Historical Understanding of Legal Conciseness: The Case of Classical Legal Thought in America, 1850-1940, 3 Research L. and Sociology 3 (1980).

39. The best treatment of Hale's ideas is Barbara Fried, The Assault on Laissez-Faire: Robert Hale and the First Law and Economics Movement (Harv. U. Press 1998). 
book as well as a set of heroes and villains. The story-line was that of the fall of Classical Legal Thought (or formalism), its critique and partial supplanting with Progressive legal thought. This was a Kuhnian narrative. But it was followed by another-the resurgence of legal formalism in the postwar legal system and legal academy. In science, dead paradigms stay dead. In law, they never really get killed off, but hang around and Dracula-like, rise from their coffins to stalk the earth. Horwitz's villains, in the new narrative, were still those of Transformation $I$ - the forces of legal formalism, resurgent in the postwar world as Herbert Wechsler's "neutral principles," the "legal process school of jurisprudence," and several generations of purportedly value-free social science, from legal-realist empiricism to law-and-economics. The heroes were the jurists that Novick called "cognitive relativists," fully aware of the value-laden, theory-dependent, necessarily political character of all tools for understanding and regulating the social world, shorn of the illusion that law is or ever can be objectively interpreted or apolitically neutral among contending interests and policies.

Hovering above these two meta-narratives was another methodological commitment, Horwitz's general dislike of overly complex stories and explanations. This commitment too has its roots in the revolt against the $1950 \mathrm{~s}$, when historical scholarship worshipped complexity-irony, multiplicity, particularism-as the antidote to the simplifications of "ideology." The cult of complexity in the 1950s, of the tragic sense of limits on human possibilities, as Peter Novick put it, "with its inevitable strong suggestion that any but the most piecemeal and modest tinkering with the social mechanism was ill-fated" ${ }^{\prime 40}$ had led into conservative resignation, either complacent or depressed, to the status quo. By way of recoil, Horwitz took from this account a strong preference for clear, vigorous and stripped-down narratives and explanations. This commitment led him to his sharpest point of disagreement with colleagues in Critical Legal Studies, who were disposed to argue that the association of any given set of legal doctrines or principles methods with legal-political outcomes was never anything but contingent, because types of legal argument could be "flipped" so as to be turned to any imaginable purpose. No, Horwitz said: at any given time, legal-argument-types-such as doctrines of causation or absolute-property or strict-liability or the real-entity theory of the corporation-tend to favor privilege, have an inbuilt "tilt" towards particular outcomes and not others. ${ }^{41}$ The master-tilt for the second half of Transformation II-which if I am not mistaken is completely contrary to or at least very different from the master-tilt of Transformation I and the first half of Transformation II (in which formalists appear as "Old Conservative" individualists hostile to corporate enterprise)-is that formalism, whether of Classical Legal Thought, empirical social science, neutral principles, or law-and-economics, is inherently conservative, and relativism socially progressive. Horwitz's recent short book on the Warren Court carries this theme forward by characterizing the Court as intentionally

40. Novick, supra n. 20 , at 324.

41. See e.g. Horwitz, supra n. 35, at 106 (discussing ideological uses of legal theories of the corporation). 
committed to policy-making for an instrumental purpose, the strengthening of democracy-rather than as, let us say, the elaboration of natural rights. ${ }^{42}$

I have gone into all this because I believe it was precisely this combination of narrative, meta-narrative, and methodological commitments that gave rise to most of the-as I say, comparatively very gentle-quarrels between Horwitz and the reviewers of Transformation II. They-and I was one of them-found the paradigms too monolithic, the paradigm-shifts too sharp, and the identification of theoretical with political positions (the major "tilts") too neat. What is one to make of Holmes, for example, a radical skeptic about legal objectivity, but in most respects a rock-ribbed political and economic conservative? Or Morris Cohen, a liberal in politics, but strenuous anti-relativist in methodology? Or Thurman Arnold, an almost pure nominalist in legal theory, a scientific positivist in economic theory, and an ultra-orthodox promoter of competitive capitalism as antitrust chief? More generally, have not most of the great progressive sociallegal movements in the American tradition-for universal suffrage, the abolition of slavery and racial segregation, the emancipation of women, labor's rights to organize and strike-drawn upon wholly abstract and formal conceptions of natural equal rights to liberty and justice?

But on one point even the most negative reviewers of Horwitz's two books agreed. This was substantial, original, path-breaking work. Even when apparently mistaken in matters of fact or problematic in matters of interpretation, this was work that probed deeply and provoked, and by so doing aroused legal and historical scholars to wakefulness and effort as well as protest and praise. They might challenge or disagree with it, angrily or respectfully, but they felt they had to engage with it, and by so doing stimulated a large part of the great new flourishing of legal history that began in the late 1970s and is still going strong. Morton Horwitz did a lion's share of the initial hard work, mixed the brew, and stirred the pot. We all owe him a tremendous debt.

42. Morton J. Horwitz, The Warren Court and the Pursuit of Justice 114-15 (Hill \& Wang 1998). 